\title{
Interaction between Online Banking and its Impact on Financial Performance of Banking Sector:- Evidence from Indian Public Sector Banks.
}

\author{
Rupesh Roshan Singh, Navneet Kaur
}

\begin{abstract}
The online banking is emerging to the enormous strength. There are many industries set up to provide technological assistance to the banks so that this facility easily provides to the urban as well rural areas of the nation. In today's dynamic world huge customers prefer to do the transaction through banks, they are using money transfer, bill payment, account statement and so on via. "Online banking”. This paper focuses on the effects of online banking based on the performance of top ten public sector banks in India according to the reports of RBI, Market Capitalization, total assets of the Indian bank enterprises. For this the financial ratios of the banks analyzed and this research paper is based on secondary banking data in nature.
\end{abstract}

Key-words:-Online-banking, internet, Capitalizations, RBI, ROA, ROE,

\section{INTRODUCTION OF BANKING}

Banking is one of the important and necessary for all 'bank' is derived from French word "Bancus" or "banque,i.e., a bench.

In simple words, banking is defined as any institution based on finance which accept money from the general public and deposits in to the account. Banks provides divergent facilities to the customer such as accepting of finance, lending loans to different sectors, accepting bills payables, assistance to the legislative bodies in any emergency and so on. Now a days there are many financial institution providing different services of bank as per the guidelines set by bank. It is also known as subset of financial institutions.

\section{INTRODUCTION OF ONLINE BANKING}

In current world financial scenario reaches at the peak level of cutting edge to the applied technologies. While on one hand large amount of money are required to transfer from one place to another and sometimes on the demand of customers from one account to another account. In the bygone era, it is possible to fulfill financial needs without the help of technology. Owing to huge competition among every

unit of banking enterprise, it becomes difficult for banks to

Revised Version Manuscript Received on 16 September, 2019.

Dr. Rupesh Roshan Singh, Associate Professor, Mittal School of Business, Lovely Professional University, Punjab, India.

(Email: :rupeshroshan1983@gmail.com)

Navneet Kaur, Research Scholar Ph.D. (Commerce), Lovely Professional University, Punjab, India

(Emai:davinderpaul0@gmail.com ) render variety of services to the clients, business holders, small, medium and large scale enterprises, other financial units. To overcome this situation online banking provides great assistance in banking and other financial operations.

\section{EVOLUTION OF COMPUTER BASED BANKING}

The first computer based banking came in 1980 by united American bank. Its headquarter located in United kingdom tied with radio shack to produce a secure custom modern fir its TRS-80 computer that would allow bank customer to access information securely. Services of banking available for the first year included account balance checks, loan facilities, bill payment and so on. Thousands of customers started availing these facilities and paid $\$ 25-30$ per month for the services.

The developers of United Kingdom failed in 1978 because of operational risks at the part of bank owner, Jake Butcher.

In 1994 online banking services to all customers given by Stanford federal credit' union and this was the first financial institutions and becomes second financial group in the world and first in the world in 1996.

In 1990 customers were hesitant to use on line banking and any monetary transaction through e banking they were motivated through American online Amazon.com,e-bay to initiate and make idea of using and paying for item online.

Then there was increment in the tally and by , In US almost 70-80\% banks offered online banking services. Customers grew slowly. However, The bank of America was the first bank to top three million with e-banking customer and it was more than $20 \%$ of its client base.

\section{EVOLUTION OF ONLINE BANKING IN INDIA:-}

The "internet banking" started up in late 1990s by the ICICI bank .it was the first bank who introduced e banking in India, with the growth of e banking in different sectors of the banks the customers started availing its facilities in 1996. The services provided to the customers are really beneficial for them .The "internet banking" properly established in 1999. Then, many other banks also started following this facility 
such as Housing development and finance corporation bank, Citi bank, IndusInd bank, and redundant times bank.

Online banking faced many problems at its starting phase but then started emerging because of huge benefits. For example initially nationalized bank

Was very much insecure about online banking and hesitant to implement to entire customer and large customer based market. . Then many banks started following online banking such as SBI, Canara Bank, Allahabad bank, Syndicate banks and many other banks. In 2001 SBI set up online banking and have great positive response and thus online banking started rising up.

In current scenario global and all banks motivate their customers to use e banking because it save times, transactional costs, fast, revenues and they also believe that auto -control financial transactions have more benefits and provides more privileges. Online banking has thus provides many benefits to the customers and various banking service.

\section{LITERATURE REVIEW}

Kagan et al., 2005 in their research paper "Interaction Between e- Banking and Performance of bank: the case of Europe" e- banking is to make increase the quality of bank assets and directly affects return on assets performance, there are also indirect effects on profitability through different cost. E- Banking services decrease different average operational costs on different parts of banks,. The more developed electronic infrastructure falls cost per transaction of banking and increases profitability of banking system. The success of internet banking also depends upon the level of education of customer.

The educated customers have different demand as compare to the low level educated customer.

The costing is very high for the bank if the level of education in customer is very low and these type of customer need different features of internet banking, that increases bank cost and tends to low profitability.

According to ALPM and their research work" Modernization in Indian Banking Sector" that the development in the banking technologies sector started with the use of very new ledger posting machines and in today scenario banks are using core banking solution for providing customized services to their customers.

Different studies have been conducted in banking sector and to find out the relation between impact of information technology and bank performance and profitability of bank, modernization and computerization is one of the major factors which improves the banking efficiency and it has been observed for public sector banks to improve their efficiency and productivity by using efficient information technology and new software.

Schlie in their research paper in year 2008, titled "The impact of e- banking on the performance of Romanian banks: Schlie used two approaches DEA and PCA" he examined that the bank performance increseas with the use of internet banking. In the study of Schlie he carried out on a sample of more than 100 banks from 6 European countries (Denmark, France, Finland, Germany and Sweden), that banks do not have an aversion regarding the adoption of internet banking services, the legacy effect in the case of this financial innovation being rather overstated.
Ozsoz and Onay (2013) underline that e- banking services, as a used for distribution channel, allow banks to switch to a "click and mortar" approach so that clients can conveniently open different accounts, create bank deposits, transfer funds to any accounts, and make online payment at lower cost compared to the old traditional banking that leads to a higher banking efficiency.

According to Atay in their research in 2008, The ebanking services is very important to improve the profitability and efficiency of the bank.

According to the research done by Ali Yachted in 2001 in his research paper "Impact of Technology on Banking Sector in India "he stated that banking transaction processing load is taken over by new technology, recent banks are concentrating on different marketing approach and re-engineering their business Model.

Yousafzai et al. (2009); Pieters (2010); Avizienis et al. (2004) in their research work named as "Impact of Online Threats on Usage of E-Banking" it is described that online banking accounts belonging to retail customers are raising doubts about the and fraud-detection and authentication mechanisms now mostly used by banks. In most of those cases, online criminals obtained a retail customer's authenticated banking log-in credentials by illegal means. Such online threats have prompted government regulators to call on financial institutions mostly banks to rethink their security systems. Online thefts mostly occurred because the customers failed to adequately protect their banking credentials. These kinds of online thefts have impact on public relations because banks are not required to reimburse stolen amount. According to trust in the banking sector has not yet been fully translated in the online environment because trust is difficult to achieve without face-to-face interaction and it is doubtful that artificial agents are capable of trusting and/or being trusted. Technology-related variables are also imperative as traditional factors in predicting customer's behavior in online environment. Online threat landscape has been changed because online attackers have adopted more intricate methods to break online verification techniques.

In 2011 one the research done by Ravinder, he predicted the profitability of major banks in India in his study the SBI performed better in terms of different market ratio like EPS and dividend payout ratio, the other banks performance was also good and PNB performed better in terms of return on equity and operation profit margin

Statista, 2017 from (2015 to 2017) it is explained in the research journal that "Changing Face of Online Banking in India: Technological Transformation Perspective" that Online social networking: According to the experts Indian online networking clients were expanded from around 145 million to 200 Million i.e. around $28 \%$ development and it will reach up to 380 million by 2022 . While total number of mobile web clients in India in 2015 was around 260 million and anticipated that would grow 512 million by 2022 . 
Mingqi Li, Tiananqi Feng,(2015) in US bank holding based research work named as "Relationship between non-interest income and valuation of bank. it studied the impact of non intrest income on different valuation of bank.. Because these -interest income reduces the instability of bank income.

It is assumed that valuation is very high with higher non interest income. By focusing on valuation rather than profitability, it avoids some of the hurdles of measuring bank performance using profitability.

(Moumita Deb Choudhury , 2017) in the research paper of "Changing Face of Online Banking in India: Technological Transformation Perspective" on 8th Nov 2016, Demonetization has given a momentum to digital payments in India and on the other hand, advanced technologies are set to take the banking and financial sector by storm, which in turned generated many opportunities for technology investments into digital payments infrastructure. The digital transaction is growing with very fast rate and expected to cover entire areas including urban and rural.

Annual Report (RBI 2017-18), According to the report

IMPS, RTGS and NEFT are increasing day by day

\section{OBJECTIVES OF THE STUDY}

To analyze the impact of online-banking in Indian public sector banks.

To measures the financial performance of top public sector banks after online-banking.

To ascertain the development in the banking system of India because of the online banking.

To find out main reasons behind the use of online-banking in India.

\section{RESEARCH METHODOLOGY \& RESULTS}

This research study is based upon the financial performance of top ten public sector banks. To analyze the data in a proper way basic stress put on ROA and ROE for the years 2018 and 2019. To make the comparison data is taken from the 10 largest public sector banks according to the Capitalization of public sector Banks and total Assets on the basis of data given in money control and also from the different website and the RBI statistics, the online data of NEFT,RTGS and others are collected through RBI Bulletin and RBI annual reports and also data published by Indian Banking Associations, Economics survey of India and others financial survey reports.

"TABLE 1"

\begin{tabular}{|l|l|l|l|l|}
\hline & \multicolumn{2}{|c|}{ ROA } & \multicolumn{2}{c|}{ ROE } \\
\hline PSB & 2018 & 2019 & 2018 & 2019 \\
\hline SBI & -0.18 & 0.02 & -3.37 & 0.39 \\
\hline BOI & 6.02 & 6.52 & 81.82 & 96.12 \\
\hline IDBI & 4.67 & 9.849 & 5.23 & 3.992 \\
\hline PNB & -1.6 & -1.28 & -32.85 & -24.2 \\
\hline CBI & -1.56 & -1.7 & -28.38 & -29.79 \\
\hline Canara bank & -0.68 & 0.04 & -14.51 & 1.16 \\
\hline BOI & 5.83 & 7.4 & 20.38 & 16.78 \\
\hline Indian bank & 7.3 & 6.92 & 38.41 & 40.36 \\
\hline UBI & 5.14 & 4.93 & 21.47 & 13.75 \\
\hline Vijaya bank & 5.26 & 5.98 & 8.16 & 8.14 \\
\hline
\end{tabular}

The population of this study comprises of PSB such as

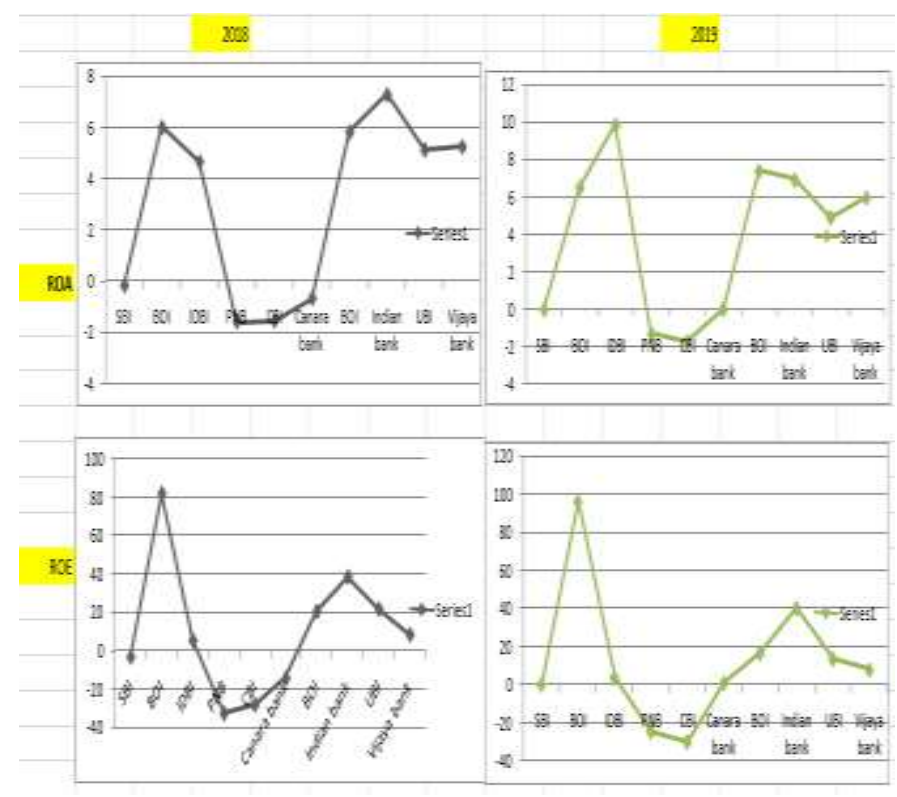

SBI, BOB, IDBI, PNB, BOI, Central Bank of India, Canara Bank, Indian Bank, Union Bank of India,. The SBI shown increase in productivity with huge privileges from online banking. It shown slightest fall in 2018 but again achieving target and goals successfully in 2019. The impact of online banking shown tremendous rise in $2^{\text {nd }}$ position public sector Bank of Baroda, the return on assets as well as return on equity both are raised. Subsequently, Industrial bank of India have great rise in figures from 2018 to 2019. Probing ahead, Punjab national bank also shown tremendous rise with fall in negativity figures from previous data. Furthermore, Central Bank of India also has shown good trends by implementing online banking. The Canara Bank moved from negative output to positive in 2019. The Bank of India and Indian bank have great rise in figures owing to the impact of online banking.

In an epilogue, the online banking has positive results on the performance of banks. Since the customers feel more convenient and comfort to access the information while sitting at their homes and also performing jobs. Many industries are providing help to make it more easy and also to reduce chaos and confusion similar internal functioning are preferred. Moreover branch banking is converted into online banking owing to huge benefits. But banks have to focus on eliminating issues related with securities of online banking and easily used web-sites would be organized. Also, there is need of the hour to work, more on the research field of online banking.

\section{REFRENCES}

1. Goel, M. (2013). Impact of Technology on Banking Sector in India. International Journal of Scientific Research, 2(5).

2. Stoica, O., Mehdian, S., \& Sargu, A. (2015). The impact of internet banking on the performance of Romanian banks: DEA and PCA approach. Procedia Economics and Finance, 20, 610-622. 
3. Mansoor Khan, M., \& Ishaq Bhatti, M. (2008). Islamic banking and finance: on its way to globalization. Managerial finance, 34(10), 708-725.

4. Tidd, J., \& Bessant, J. R. (2018). Managing innovation: integrating technological, market and organizational change. John Wiley \& Sons.

5. Chavan, J. (2013). Internet banking-benefits and challenges in an emerging economy. International Journal of Research in Business Management, 1(1), 19-26.

6. Gulati, V. P., Sivakumaran, M. V., \& Manogna, C. (2002). IT framework for the Indian Banking Sector. ASCI Journal of Management, 31(1), 67-77.

7. Nagaraju, S., \& Parthiban, L. (2015). Trusted framework for online banking in public cloud using multi-factor authentication and privacy protection gateway. Journal of Cloud Computing, 4(1), 22.

8. Kiljan, S., Vranken, H., \& van Eekelen, M. (2018). Evaluation of transaction authentication methods for online banking. Future Generation Computer Systems, 80, 430-447.

9. Tunay, K. B., Tunay, N., \& Akhisar, İ. (2015). Interaction between Internet banking and bank performance: The case of Europe. Procedia-Social and Behavioral Sciences, 195, 363-368. 